\title{
The impact of local NGOs on sustainable tourism in Valle de Bravo, México
}

\author{
R. Segrado \& F. Farmer \\ Universidad de Quintana Roo, México
}

\begin{abstract}
Non Governmental Organizations (NGOs) can play an important part in the development of sustainable tourism. While this may be accepted and their presence facilitated at national level, their actual impact at local level may not be all that could be desired. This paper presents the findings of a case study into the effectiveness of NGOs in promoting sustainable tourism in the rural district of Valle de Bravo in central Mexico. The study forms part of a larger project covering a wider geographical area but The Valle de Bravo area is of particular interest as a poor area which is nevertheless a destination for higher socio- economic level national tourism. Data was obtained through interviews with workers, professionals and administrators in three NGOs working in the area as well as local government departments. This data was triangulated with structured observations carried out in the field, and the results analysed to determine the problems faced by both tourists and the local community, and the limitations and opportunities for positive action in developing tourism and safeguarding the environment. It was found that in general the local community rejected the activities of the NGOs, with participation in their projects limited to the women of the community. The NGOs themselves were found to lack technical staff, funding, and the support of local government in both social and environmental protection projects. The impact of NGOs on protecting the environment was found to be minimal, and the current destruction of the natural environment by both tourists and the local community seems likely to continue. It is argued that to be effective, NGOs will need better technical staff and funding, better coordination between the different NGOs and more support from all levels of government, both local and national.
\end{abstract}

Keywords: tourism, sustainability, $N G O s$. 


\section{Environmental impact of tourism}

Like any economic activity, including those classified as ecological, tourism consumes resources and produces waste. Although tourism may compete with other activities for resources on some occasions, on others it may complement those activities. Nevertheless, even with careful planning, the environmental impact of tourism is always ambivalent in every respect [1-4]. Tourism has a positive effect on the socio-economic and political development of many countries: it helps create employment, reduces emigration, promotes markets for local products, stimulates both national and international investment, and develops and strengthens concepts of sustainability resulting in awareness and respect for both the natural environment and local culture. Amongst the negative effects are the increased occupation of land for development, consumption of water and energy, the destruction of landscapes by new buildings and the supporting infrastructure, the generation of more wastes both solid and liquid, the introduction of exotic species of plants and animals, population migration to tourist destinations, the loss of traditional values and increase in cultural diversity, the growth of prostitution and sexual tourism, drug trafficking and gangsterism, increase in natural disasters such as forest fires and increase in prices affecting the local population.

For these reasons, it is widely acknowledged that tourism is not a universal panacea, and that tourism destinations have generated negative impacts ranging from slight to extensive in the natural, cultural and social environments. It is also clear that the damage caused by tourism can result in the destruction of the destination itself, as has occurred in Mexican resorts such as Acapulco and Cancun, contradicting the belief that tourism is a generator of beneficial development. One explanation or this is that much current tourism development is based exclusively on economic interests, without considering environmental impact caused by the creating of infrastructure and changes in land use together with the resulting socio-economic changes. However, in spite of the emphasis on economic factors and the acknowledged impact on the natural environment, tourism is still considered a vital instrument for the protection of natural assets. Income from tourism can help finance the preservation of natural parks and the protection of ecologically sensitive areas, the promotion of more acceptable alternatives as well as the environmental education of both the tourists and the local population. Such benefits depend on development strategies aimed at sustainable tourism.

\section{Sustainable tourism in Mexico}

The National Tourism Plan 2001-2006 [5] has established as one of its fundamental principles that 'governments, authorities, non governmental organizations (NGOs) and local communities should direct their efforts towards the integrated planning of tourism.' The Plan acknowledges that local actors are extremely important in the protection of the natural environment and that 'the 
tourism industry, in collaboration with other groups and NGOs related to tourism, should develop frameworks for action that guarantee sustainable development.'

These principles imply the implementation of processes for the protection and exploitation of resources at local level, the site of the tourism resource, in a way that protects that resource, satisfies the tourist, gains benefits for the local population, and avoids or reduces negative effects. This can be done through the administration of tourism resources and limitation of damage caused by tourism through local associations and organizations.

Amongst these local associations and organizations, NGOs can exercise a regulatory and supportive function as well as acting as the main protagonist where the State is unable to intervene or the management of local community resources shows evidence of unsustainablility. In fact, the role of NGOs has increased substantially in recent years. This is the case in Valle de Bravo, in the Estado de México, where the NGOs are dedicated to the protection of the natural environment.

\section{Valle de Bravo: a case study in sustainability}

The study reported here concerns only the natural environment. It was found that no official statistics concerning the impact of tourism on the natural environment existed, nor had any previous studies been carried out. Data for this study was obtained from structured interviews with two key actors in local government and five representatives of three NGOs, field observations and visits to all the natural attractions listed below, basing the methodology on Ander Egg [6]. In this case, the research was facilitated because the researcher had previously been an active participant in the local community.

Data from interviews was triangulated with structured observations carried out in the field, and the results analysed to determine the problems faced by both tourists and the local community, and the limitations and opportunities for positive action in developing tourism and safeguarding the environment. The three NGOs were selected for study because they have a well established and stable structure and because the natural environment is their main concern.

The research was carried out over a six month period by a multidisciplinary team, principally from a planning background, and interviews and observations were conducted weekly. In addition, collaborative research was carried out with the NGOs observing the planting of trees, clandestine felling in forest zones, and evaluating the illegal sale of firewood and ornamental plants to tourists. The study was funded by the National Council for Science and Technology (CONACyT).

Valle de Bravo is a rural administrative district with a population of 25,409 inhabitants [7] where half the population live in the main town. It is located in the state of Estado de México, $90 \mathrm{~km}$. from Toluca, the state capital. From being an agricultural community in 1960, it has been transformed into an attractive zone for investment in private houses by artists, famous singers, politicians and business tycoons. In addition, there has been private sector investment in 
developing new housing estates and holiday homes. Nevertheless it is necessary to recognize the difference between the main town, where the main activity is now residential tourism, and the other communities which are dedicated to agriculture and forestry [8].

According to the Municipal Development Plan 2003-2006, local government is committed to promoting ecological and adventure tourism through various activities:

$\begin{array}{ll}\text { - } & \text { Observation of natural attractions. } \\ \text { - } & \text { Trails } \\ \text { - } & \text { Hangliding } \\ \text { - } & \text { Walking tours } \\ \text { - } & \text { Horseback riding } \\ \text { - } & \text { Cycling } \\ \text { - } & \text { Sport fishing } \\ \text { - } & \text { Boat tours }\end{array}$

To this end, local government has promoted the natural attractions of the area, amongst which the coniferous forest, exuberant vegetation and the lake are outstanding. Other attractions are the Peña del Principe (a rock outcrop in the centre of the town), the lakeside promenade and boat landing stage, the cultural institute, the Avándaro waterfall, the Velo de Novia fountain (also a park and ecological reserve) and the Bosque de Monte Alto (natural mountain forest reserve). There are other natural attractions in the outskirts of Valle de Bravo, such as the Bosencheve national park, and the forests where the Monarch butterflies rest. There are no tour operators or travel agents, nor are there any important hotels, although there are small tourist shops, weekend restaurants and small three star hotels. In spite of the lack of provision, significant income is generated by tourism, principally from housing through taxes, construction, and construction permits.

As a result of tourism, the local community is suffering serious economic, social, natural and cultural changes, principally in the rise in the cost of living, the adoption of other lifestyles and customs, destruction of the forest and loss of natural spaces. In addition, the lake is being contaminated by sedimentation and other waste, and local traditions are being weakened or have disappeared completely. Nevertheless, Valle de Bravo enjoys a strong communal identity, and there is the will to protect the natural environment and maintain the culture, especially in the young adult population. This is reflected in the growth in recent decades of community organizations dedicated to the protection of the natural and social environment.

\subsection{The NGOs of Valle de Bravo and their relations with the community}

Because of demographic, infrastructure and logistical constraints, there is a concentration of the NGOs in the main town of the region. The main NGOs are Patronato Pro-Valle and two ecological groups, Intocables and Biocenosis, each with its own strategies and areas of influence depending on their objectives. They all share the principal objective of protecting the natural heritage of the lake and forest. There is no organization concerned with tourism. The NGOs 
work on raising awareness, training, education, management and research. They raise funds through donations, subsidies and events such as raffles, sports competitions and fiestas and so on. There is little international support for these groups although some of them have developed social or ecological projects of international significance.

The Patronato Pro-Valle was founded in 1984 to combat the spread of water iris and protect the natural environment in general, but thanks to the contributions of members and sympathizers over the years, the organization has diversified to form five specialized committees with particular responsibilities:

a) The lake

b) Urban development

c) Health

d) Forest resources

e) Culture

In the field of the natural environment, the organization carries out annual campaigns against the spread of water iris, participates in the Municipal Development Plan and monitors its implementation, organizes various meetings of the community and initiates campaigns for reforestation and soil restoration.

The Intocables group, in contrast with the Patronato Pro-Valle, operates through community participation with the few subsidies that it can obtain. The group started to work on an atlas of fauna of Valle de Bravo as a community project, but it was abandoned because of lack of funds and lack of support from local government. Currently, members of the Intocables receive invitations from other groups to participate in reforestation and in cleaning up the lake and the forest. These activities are carried out once a year to show concern for the whole community, not just members, and because the appearance of the lake and the forest are valued. There are also monthly meetings to carry out cleaning and erosion prevention work.

The Biocenosis group, dedicated to protection of the natural environment, is based in the state of Yucatan and was started for the conservation of forest life. The organization is concerned with the recuperation of populations of species threatened with or in danger of extinction, conservation of natural habitats, and the conservation and responsible exploitation of natural resources. The group has carried out various projects for local communities, including the establishment of nurseries for orchids and other plants for sale to tourists, although there have been problems due to lack of finance. The group also has annual campaigns for reforestation and soil restoration. The last project undertaken by the group during the period of this research study was a community initiative to obtain funding from State and Federal authorities. The group has frequent meetings with the representatives of public bodies as well as participating in workshops on rural development.

All the groups mentioned above promote the growth and development of tourism, through collaboration with the public and private sector, or through raising awareness and training given directly to the local community within specific projects in relation to the natural environment. The NGOs attempt to influence directly the behaviour of both the local inhabitants and the tourists, by 
means of leaflets, posters, and radio transmissions where recommendations are made with regard to protection of the natural environment, waste disposal, social behaviour, and so on.

\subsection{NGOs and the local authority}

NGOs also influence the growth of tourism through participation in determining the policies and zoning of the Municipal Development Plan, limiting and fixing directly the growth of the tourism centres, although there have been conflicts between the NGOs and local government over these issues.

Interviews with local government employees have shown that local government values the formation of NGOs as they reflect an individual and social concern and awareness about the protection of natural resources exploited by visitors without benefiting the community. However, not everyone holds the same opinion. One representative of an NGO reported that the local authority has accused the NGOs of not allowing local people to make a living. This because the NGOs are perceived by the local authority to protect the natural environment as an end in itself, and have succeeded in establishing penalties for invading the forest and exploiting natural resources. The result is that local residents are restricted from using resources such as firewood, orchids and other ornamental plants to supply tourism demands.

Clearly, it is necessary to limit environmental damage by residents as well as tourists. Nevertheless, some strategies directed to this end could conflict with other local benefits. For example, restricting access to the forest by peasants collecting firewood or basic foodstuffs because the tourists want security or because the NGOs want to protect the environment only serves to increase differences between weekend residents and tourists on one hand and the local community on the other.

Both local government officials and employees of the NGOs were found to agree that tourism as an economic activity is prejudicial to the natural environment. This is due to excessive use, damage and destruction of natural resources by both tourists, for recreation, and residents to supplement their income. According to one respondent, concern about the local environment is restricted to the NGOs and a few other people. As an example, this respondent cited attendance at workshops about the natural environment. The respondent claimed that workshops organized in the communities were attended only by women, that men only participate except to obstruct the creation of reforestation zones to cultivate the land or occupy it for illegal settlements, and that attendance was only high in children's events.

\subsection{Collaboration between NGOs}

During the research period, no collaboration was observed between different NGOs, although they share two central objectives: protection of the lake from contamination and sedimentation, and protection of the coniferous forest.

However, a few months after the research period ended, NGOs working together did in fact achieve significant social and economic benefits for the local 
community by establishing a monarch butterfly reserve. The reserve employs local residents as forest guides and charges 150 pesos (\$15 US) for the service. This income has avoided the mass emigration of the male population that has occurred in similar circumstances elsewhere in Central Mexico, as well as improving the protection of the butterflies. Credit is due to both local and state level NGOs for making this possible.

\subsection{Limitations of the NGOs}

The NGOs are dependent on voluntary donations for finance, which means that they are affected by the politics and priorities of their donors. In addition, competition for external resources means that the NGOs are driven more by offer than by demand, so that they generate programmes of action that they need to 'sell' rather than responding to the needs of the local population [9]. In the Valle de Bravo study, this was reflected in programmes that showed more concern for flora and fauna than for the people of the area. The NGOs have not reached an adequate level of self finance, nor do they have the capacity for self management and efficiency, resulting in a constant search for income which also limits productive activity.

Although the NGOs are considered to be representatives of the community, they have little social, political or financial backing. In addition, as the community is small, their capacity to act is restricted by coercion, repression, or political convenience.

Nearly all the local NGOs, with a few notable exceptions lack qualified professional members, so that they are unable to make a contribution to projects with a high technical content, or make good use of scarce resources.

In the search for sustainability, the NGOs see tourism as a useful tool for helping to conserve natural environments. However, tourism in itself does not bring economic benefits. Rather, it is tourism activities that have the capacity to bring in economic resources due to the high social status of the destination.

\section{Conclusions}

NGOs are valued both by the community and by local government, but their effectiveness is diminished by both internal and external factors. Both internal and external factors can be addressed, and in the case of Valle de Bravo there are real opportunities for a successful collaboration between NGOs, the community and the local, state and national authorities. The principal recommendations for NGOs arising from this study are:

Internal Factors:

- Include appropriate professionally qualified team members in projects.

- $\quad$ Address the needs of the community.

- Adopt efficient and effective management procedures.

External factors:

- $\quad$ Local, state and national government financial support

- Improved collaboration and reduction of overlap of functions between NGOs. 


\section{References}

[1] Jurdao, F., Los mitos del turismo, Editorial Endimión: Madrid, España, 1992

[2] McLaren, D., Rethinking tourism and ecotravel, Editorial Kumarian, Connecticut, USA, 1998.

[3] Mowforth, M. \& Munt, I., Tourism and sustainability, Editorial Routledge, New York, USA, 1998.

[4] OMT Organizacion Mundial del Turismo, Guia para administradores locales: Desarrollo turístico sostenible. Editorial OMT, Madrid, España, 1999.

[5] SECTUR Secretaría de Turismo, Plan Nacional de Turismo 2001-2006, Editorial SECTUR: México, D.F., 2001.

[6] Ander Egg, E., Metodología y práctica del desarrollo de la comunidad, Editorial Lumen: Buenos Aires, Argentina, 1998.

[7] INEGI Instituto Nacional de Estadística, Geografía e Informática, XII Censo General de Población y Vivienda 2000/Población/ Sistema Municipal de Base de Datos (SIMBAD), Retrieved from: http://sc.inegi.gob.mx/simbad/index.jsp?c=125 2006.

[8] González, H., Valle de Bravo. Monografía Municipal, Editorial Instituto Mexiquense de Cultura: Toluca, México, 1999.

[9] Diaz Albertini, J., Capital social, organizaciones de base y el Estado: recuperando los eslabones perdidos de la sociabilidad, en Capital social y reducción de la pobreza en América Latina y el Caribe: en busca de un nuevo paradigma. Atria, P. et al (Compiladores). Editorial CEPAL: Santiago de Chile, Chile, 2003. 